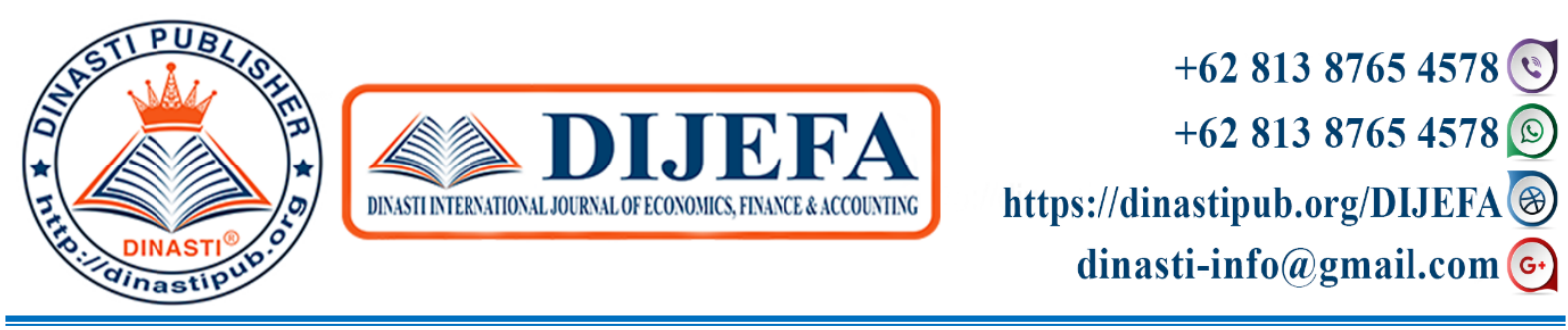

\title{
THE EFFECT OF MACROECONOMIC FACTORS ON THE NUMBER OF CORPORATE SUKUK OFFERS IN INDONESIA
}

\section{Haerul Ependi ${ }^{1}$, Hakiman Thamrin²}

1) Mercu Buana University, Jakarta, Indonesia

${ }^{2)}$ Mercu Buana University, Jakarta, Indonesia

\begin{tabular}{c|l}
$\begin{array}{c}\text { ARTICLE INFORMATION } \\
\text { Received: 27 July 2020 }\end{array}$ & $\begin{array}{l}\text { Abstract: This study aims to analyze the effect of } \\
\text { macroeconomics factors on corporate sukuk in Indonesia in } \\
\text { the short and long term. The independent variable is }\end{array}$ \\
Issued: 24 September 2020 & $\begin{array}{l}\text { Inflation, Economics Growth, Total Money Supply, Foreign } \\
\text { Exchange Rate and Bank Indonesia (BI) Rate. Whereas the } \\
\text { dependent variable is the number of sukuk corporations } \\
\text { offered. The results of this study indicate that the Inflation, } \\
\text { Economics Growth, Total money supply, and BI Rate have } \\
\text { no significant effect on the number of corporate sukuk } \\
\text { offered. While Foreign Exchange Rate has significant effect } \\
\text { on the amount of corporate sukuk that offered. In the short } \\
\text { term period, the total money supply has significant influence } \\
\text { on the number of sukuk corporations offered while the rest } \\
\text { have no significant effect. } \\
\text { author }\end{array}$ \\
Keywords: Macroeconomics, Corporate Sukuk, Inflation, \\
Economics Growth, Total money supply, Foreign Exchange \\
Rate, BI Rate
\end{tabular}

\section{INTRODUCTION}

The first successful Islamic bond issuance was the Government Investment Issues (GII) formerly known as the Government Investment Certificate (GIC) - conducted by the Malaysian government in 1983. But again the market for these securities did not develop due to slow innovation and the absence of support from Islamic financial institutions. In 2002, the issuance of world sukuk was recorded at 4.9 billion US dollars. The total developments that occurred until 2007 is US \$ 71.5 billion, 14 times increase compared to 2002. But there was a drastic decline in global global sukuk issuance which only recorded sales figures of US \$ 14.1 billion in 2008. This year sukuk sales were reduced by 54 percent compared to sukuk sales in 2007.

Sukuk sales increased again in 2009 to US \$ 20.2 billion. Then it decrease again. In 2010 international global sukuk sales were recorded at only 17.1 billion US dollars, decrease by 15 percent from sales in 2009. It was recorded that until February 2011 the total global issuance of all global sukuk issuances reached 125.7 billion US dollars from year to year. It has almost doubled 
in just over four years. No wanting to waste the potential sukuk that has been issued by Malaysia, Indonesia began to look to participate in issuing sources of funding with low risk but with great potential.

It was started by PT Indosat Tbk which issued a corporate sukuk on October 30, 2002 with a mudharabah contract valued at 175 billion rupiah. But at that time there were no adequate regulations. The regulatory framework still uses Conventional Securities Issuance Regulations, with additional sharia compliance statement documents from DSN MUI (National Sharia CouncilIndonesian Ulema Council). Finally, the Fatwa of MUI DSN No.32 and No.33 were issued in 2002 as a basis for issuance of sharia bonds. Since then, the issuance of corporate sukuk in Indonesia has grown rapidly. After a while with the issuance of the first corporate sukuk, the state sukuk (SBSN) series IFR0001 and IFR0002 were issued by the government as a funding instrument used to finance the budget deficit. Previously the government also issued Law Number 19 of 2008 concerning State Sharia Securities (SBSN) on May 72008 as a legal basis for the issuance of SBSN. This sukuk was issued on August 27, 2008 with an ijarah agreement valued at 2,714.7 and 1,985 billion rupiah. IFR series sukuk are sukuk issued to institutional investors who generally have a lot of sukuk funds to buy sukuk.

In addition to institutions, the government also issues sukuk for individual investors, namely state retail sukuk. The first sukuk of this type was SR001 which was issued on February 25, 2009 with a value of 5,556.29 billion rupiah. Since it was first published in 2002 until 2011, the issuance of sukuk has developed very encouraging at 40292 percent. Corporate sukuk which was originally only issued by one issuer with a value of 175 billion rupiah, in 2011 has been issued by 48 issuers with a total value of 7915.4 billion rupiah. The amount of value has increased tenfold in just seven years. In addition, there were also registered sukuk worth 2,039.4 by 17 issuers.

\section{LITERATURE REVIEW}

\section{Sharia Bonds}

Sharia bonds can be defined as long-term securities based on sharia principles issued by issuers to sharia bondholders, which require issuers to pay income to sharia bondholders in the form of profit sharing margin/fees, as well as repayment of bond funds at maturity. Fatwa ( DSNMUI No.33 / DSN-MUI / IX / 2002 ).

\section{Inflation}

According to Sukirno (2004:333) Inflation is an increase in the price of goods and services, which occurs because demand is greater than the supply of goods in the market.

\section{Foreign Exchange Rates}

The amount of domestic money needed, namely the amount of rupiah needed, to obtain one unit of foreign currency (Sukirno, 2006: 397).

\section{BI Rate}

The BI rate is the benchmark interest rate of Bank Indonesia and is a signal (stance) of Bank Indonesia's monetary policy. BI rate is the interest rate of Bank Indonesia set at quarterly RDG (The Boards' Meeting) to take effect during the current quarter (one quarter), unless determined differently by monthly RDG in the same quarter ( http://www.bi.go.id )

\section{Total Money Supply}


Definition of money supply has been divided into two senses, namely the limited and broader notion. In a limited sense, money supply is currency in circulation plus demand deposits which are owned by individuals-individuals, companies, and agencies - bodies government efforts (Sukirno, 2001: 236).

\section{Economic Growth}

Economic growth used in this study is an indication of an increase or decrease in national income which can be seen from the total amount of GDP according to business at constant 2000 prices. The GDP data in this study was also treated because the data published by BPS were quarterly data.

\section{Thinking Framework}

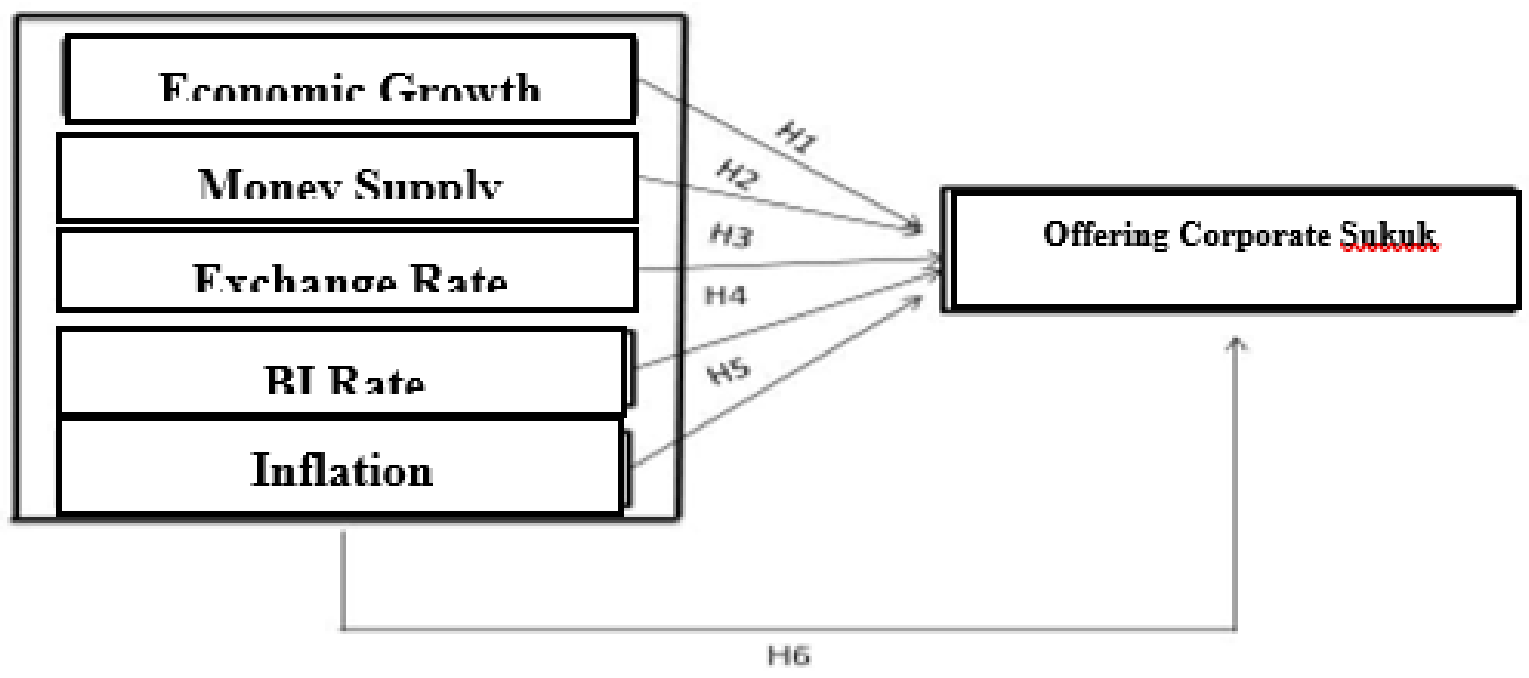

Figure 1: Thinking Framework

\section{RESEARCH METHODS}

\section{Research Design}

This research consists of quantitative methods and descriptive analysis methods. Descriptive analysis method is used to explain the condition of sukuk development in Indonesia and macroeconomic conditions in Indonesia before the issuance of sukuk. Quantitative methods are used to test the Vector Autoregressive (VAR) model which will be used to analyze the impact of sukuk issuance on Indonesian macroeconomic indicators. If the variables used in this study are stationary at the first difference, Vector Error Correction Model (VECM) method will be used.

The data collection is done by studying documents. Documents reviewed are the annual financial reports ( annual reports ) of retail companies in the 2013-2017 period published by the Indonesia Stock Exchange (IDX), previous research journals, literature studies and other relevant reading sources.

\section{Vector Error Correction Model}


Vector Autoregressive (VAR) is a special form of a system of simultaneous equations in the form of time series and only contains endogenous variables. VAR is often used to look at economic fluctuations.

\section{Stationary Test}

Stationarity test can be done with the Augmented Dickey Fuller (ADF) method in accordance with the form of deterministic trends contained by each variable. If the results of this test show the absolute value of t-ADF is greater than the absolute value of MacKinnon critical values, the data is stationary at the real level of five percent or one percent.

\section{Determination of Optimal Lag}

To get the right length of the hose, three stages of testing are needed. In the first stage, the maximum interval length of a stable VAR system will be seen. The stability of a VAR system is seen from the inverse roots value of its polynomial AR characteristics.

\section{Co-integration Testing}

Co-integration is a long-term relationship between variables which although not individually stationary, but the linear combination between these variables can be stationary (Thomas, 1997). One of the conditions for achieving long-term balance is that the balance error must fluctuate around zero.

\section{VAR Model Stability Test}

In practice, the stability of a VAR system can be seen from the inverse roots value of its polynomial AR characteristics. This can be seen from the modulus value in the AR roots table, if all the $A R$ root values are below one, then the system is stable.

\section{Variable Sequence Form (ordering)}

The need to form a variable sequence according to the causality test only occurs if the value of the residual correlation between variables in the system in the majority (more than 50 percent) becomes 0.2 . If the majority of the correlation values between the variables are above 0.2 , the specification of the order of variables in accordance with economic theory or the causality test needs to be done.

\section{RESEARCH RESULTS AND DISCUSSION}

\section{Data Description}

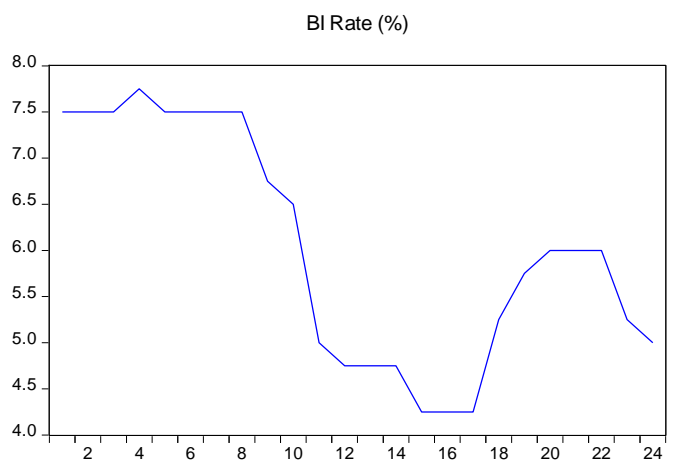




\section{Figure 2: Graph BI Rate}

Source : Researcher (2020, reprocessed)

The chart in figure 2 describes that the BI Rate decrease from the 2014 - 2019. Pretty drastic deterioration happen in 2014.

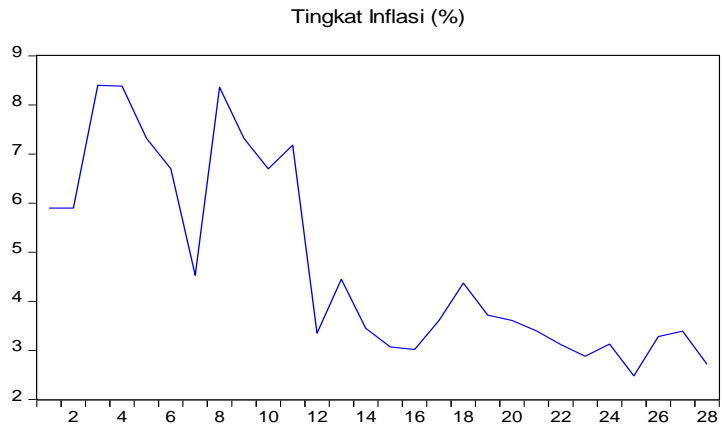

Figure 3: Inflation Graph

Source : Researcher (2020, reprocessed)

From the chart in figure 3, it can be seen that the rate of inflation in Indonesia from year to year changes significantly. The changes are towards the positive.

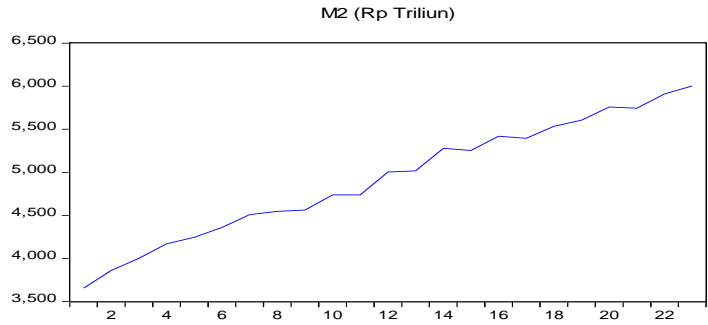

Figure 4: Graph of Amount of Money Supply

Source: Researcher (2020, reprocessed)

From the chart in figure 4, it can be seen that the amount of money circulating in Indonesia from year to year has significant changes. The changes are towards the positive. From the years 2014 - 2019 the total money supply is getting increased. 


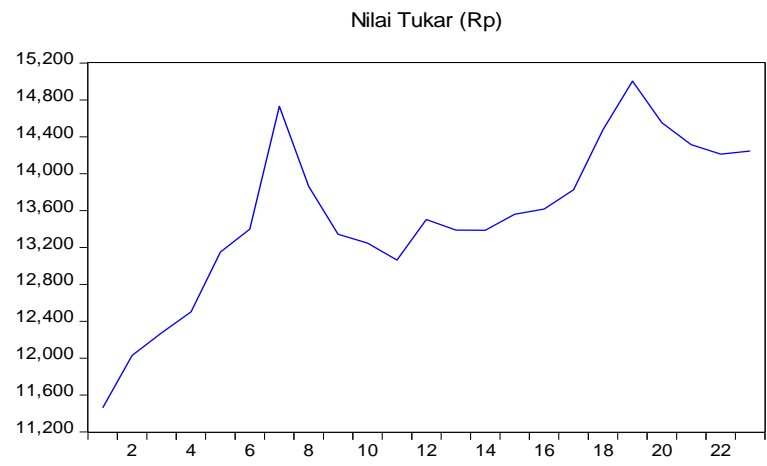

Figure 5: Graph Value Exchange

Source: Researcher (2020, reprocessed)

The chart in figure 5 describes that the value of exchange rate of rupiah against the dollar Americans are fluctuating.

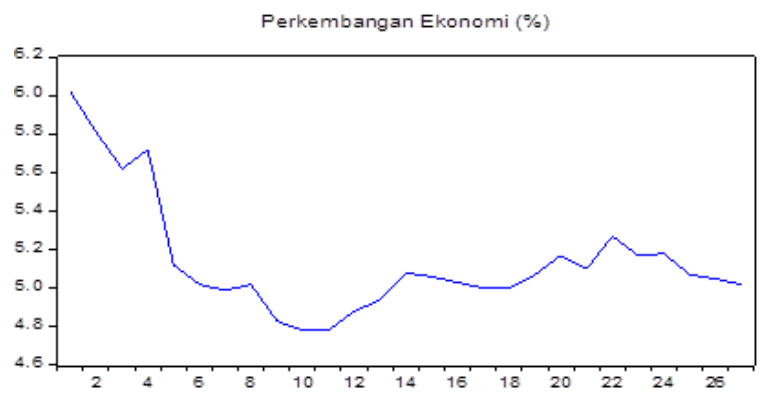

Figure 6: Graph of Economic Growth

Source: Researcher (2020, reprocessed)

From the chart in figure 6, it can be seen that the development of the Indonesia's economy from 2014 - 2019 has not been more than five. Indonesia's economic development is stuck at around a figure of five percent.

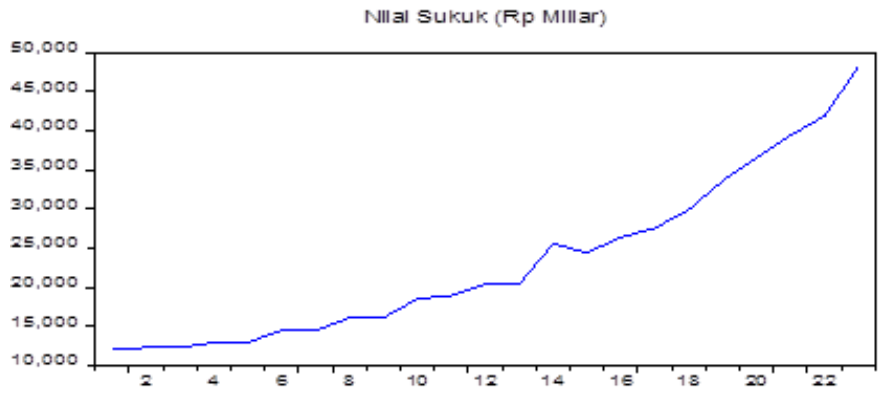

\section{Figure 7: Sukuk Value Graph}

Source: Researcher (2020, reprocessed)

From the chart in figure 7, it can be seen that the corporation sukuk in $2014-2019$ is always increasing. 


\section{Stationary Test Data}

Null Hypothesis: D(BI_RATE___ $)$ has a unit root

Exogenous: Constant

Lag Length: 0 (Automatic - based on SIC, maxlag=5)

Table 1: BI Rate Stationary Test

\begin{tabular}{lrrr}
\hline \hline & t-Statistic & Prob. $^{*}$ \\
\hline \hline Augmented Dickey-Fuller test statistic & -3.318939 & 0.0263 \\
\hline Test critical values: & 1\% level & -3.769597 & \\
& $5 \%$ level & -3.004861 & \\
& $10 \%$ level & -2.642242 & \\
\hline \hline
\end{tabular}

*MacKinnon (1996) one-sided p-values.

Source : Eviews (2020, reprocessed)

The table 1describes that the BI Rate data is stationary because the probability is less than 0,05 .

Null Hypothesis: D(TINGKAT_INFLASI___ ) has a unit root

Exogenous: Constant, Linear Trend

Lag Length: 3 (Automatic - based on SIC, maxlag=6)

Table 2: Stationary Inflation Test

\begin{tabular}{lccc}
\hline \hline & t-Statistic & Prob. \\
\hline \hline Augmented Dickey-Fuller test statistic & -4.653940 & 0.0060 \\
\hline Test critical values: & $1 \%$ level & -4.416345 & \\
& $5 \%$ level & -3.622033 & \\
$10 \%$ level & -3.248592 & \\
\hline \hline
\end{tabular}

*MacKinnon (1996) one-sided p-values.

Source : Eviews (2020, reprocessed)

From table 2, it can be seen that the Inflation data is stationary because the probability is less than 0,05

Null Hypothesis: D(M2_RP_TRILIUN_) has a unit root

Exogenous: Constant

Lag Length: 0 (Automatic - based on SIC, maxlag=4)

Table 3: Test Stationary Total Money Supply

\begin{tabular}{lrrr}
\hline \hline & t-Statistic & Prob.* $^{*}$ \\
\hline \hline Augmented Dickey-Fuller test statistic & -10.27593 & 0.0000 \\
\hline Test critical values: & $1 \%$ level & -3.788030 & \\
& $5 \%$ level & -3.012363 & \\
& $10 \%$ level & -2.646119 & \\
\hline \hline
\end{tabular}

*MacKinnon (1996) one-sided p-values. 
Source : Eviews (2020, reprocessed)

Table 3 shows that the data of the Total Money Supply is stationary because the probability is less than 0,05 .

Null Hypothesis: D(NILAI_TUKAR_RP_) has a unit root

Exogenous: Constant

Lag Length: 0 (Automatic - based on SIC, maxlag=4)

Table 4: Test Stationary Value Rate

\begin{tabular}{|c|c|c|c|}
\hline & & t-Statistic & Prob.* \\
\hline \multicolumn{2}{|c|}{ Augmented Dickey-Fuller test statistic } & -4.289227 & 0.0034 \\
\hline Test critical values: & $\begin{array}{c}1 \% \text { level } \\
5 \% \text { level } \\
10 \% \text { level }\end{array}$ & $\begin{array}{l}-3.788030 \\
-3.012363 \\
-2.646119\end{array}$ & \\
\hline
\end{tabular}

*MacKinnon (1996) one-sided p-values.

Source : Eviews (2020, reprocessed)

Table 4 describes that the data Value Rate Rupiah is stationary because the probability is less than 0,05 .

Null Hypothesis: D(PERKEMBANGAN_EKONOMI___ ) has a unit root

Exogenous: Constant

Lag Length: 0 (Automatic - based on SIC, maxlag=6)

Table 5 : Stationary Test of Economic Development

\begin{tabular}{llcc}
\hline \hline & & t-Statistic & Prob. $^{*}$ \\
\hline \hline Augmented Dickey-Fuller test statistic & & -5.096729 & 0.0004 \\
\hline Test critical values: & $1 \%$ level & -3.724070 & \\
& $5 \%$ level & -2.986225 & \\
& $10 \%$ level & -2.632604 & \\
\hline \hline
\end{tabular}

*MacKinnon (1996) one-sided p-values.

Source : Eviews (2020, reprocessed)

From table 5, it can be seen that the data on economic development are stationary because the probability is less than 0,05

Null Hypothesis: D(NILAI_SUKUK_RP_MILIAR_) has a unit root

Exogenous: Constant, Linear Trend

Lag Length: 0 (Automatic - based on SIC, maxlag=4) 
Table 6 : Sukuk Value Stationary Tests

\begin{tabular}{llcc}
\hline \hline & & t-Statistic & Prob. $^{*}$ \\
\hline \hline Augmented Dickey-Fuller test statistic & & -7.742389 & 0.0000 \\
\hline Test critical values: & $1 \%$ level & -4.467895 & \\
& $5 \%$ level & -3.644963 & \\
& $10 \%$ level & -3.261452 & \\
& & & \\
\hline \hline
\end{tabular}

*MacKinnon (1996) one-sided p-values.

Source : Eviews (2020, reprocessed)

From table 6, it can be seen that the Sukuk Corporation data is stationary because the probability is less than 0,05

\section{Optimal Lag Test}

VAR Lag Order Selection Criteria Endogenous variables: BI_RATE_M2_RP_TRILIUN_NILAI_SUKUK_RP_MILIAR NILAI_TUKAR_RP_PERKEMBANGAN_EKONOM Exogenous variables: $\mathrm{C}$

Date: 02/29/20 Time: 15:21

Sample: 123

Included observations: 22

Table 7 : Optimal Lag Test

\begin{tabular}{ccccccc}
\hline \hline Lag & LogL & LR & FPE & AIC & SC & HQ \\
\hline \hline 0 & -574.0487 & NA & $3.21 \mathrm{e}+15$ & 52.73170 & 53.02926 & 52.80180 \\
1 & -461.4887 & $153.4909^{*}$ & $3.49 \mathrm{e}+12^{*}$ & $45.77170^{*}$ & $47.85460^{*}$ & $46.26237^{*}$ \\
\hline \hline
\end{tabular}

* indicates lag order selected by the criterion

LR: sequential modified LR test statistic (each test at 5\% level)

FPE: Final prediction error

AIC: Akaike information criterion

SC: Schwarz information criterion

HQ: Hannan-Quinn information criterion

Source : Eviews (2020, reprocessed)

The next step to estimate the VAR model is determining the optimal lag that will be used in the VAR estimation. Determination of the optimal lag is important because in the VAR, the optimal lag of endogenous variables is the independent variable used in the model. Testing the optimal lag length is very useful to eliminate the autocorrelation problem in the VAR system which is used as a VAR stability analysis. So with the use of optimal lag, it is expected that autocorrelation problems will not appear again. The optimal lag length will be searched using the available information criteria. Candidates lag elected is the lag length according to the criteria of likelihood ratio (LR), Final Prediction Error (FPE), Akaike Information Crition (AIC), Schwarz Information Crition (SC) and Hannan-Quin Crition (HQ). Determination of the optimal lag in this study is based on sequential modified LR statistical test (LR) criteria. 


\section{VAR Stability Test}

Roots of Characteristic Polynomial Endogenous variables: BI_RATE M2_RP_TRILIUN_NILAI_SUKUK_RP_MILIAR_ NILAI TUKKAR RP PERKEMBANGAN_EKONOM TINGKAT_INFLASI

Exogenous variables: $\mathrm{C}$

Lag specification: 12

Date: 02/29/20 Time: 16:29

Table 8: VAR Stability Test

\begin{tabular}{ll}
\hline \hline Root & Modulus \\
\hline \hline 1.077963 & 1.077963 \\
-0.966690 & 0.966690 \\
$0.798284-0.408505 i$ & 0.896735 \\
$0.798284+0.408505 i$ & 0.896735 \\
$0.494473-0.702457 i$ & 0.859040 \\
$0.494473+0.702457 i$ & 0.859040 \\
-0.844009 & 0.844009 \\
0.814569 & 0.814569 \\
$-0.049282-0.638287 i$ & 0.640187 \\
$-0.049282+0.638287 i$ & 0.640187 \\
-0.570717 & 0.570717 \\
-0.145986 & 0.145986 \\
\hline \hline
\end{tabular}

Warning: At least one root outside the unit circle. VAR does not satisfy the stability condition.

Source: Eviews (2020, reprocessed)

Before going into further stages of analysis, the estimated results of the VAR equation system that have been formed need to be tested for stability through the VAR stability condition check in the form of roots of characteristic polynomial on all variables used multiplied by the number of lags of each VAR. VAR stability needs to be tested because if the results of estimation of VAR stability are not stable then the IRF and FEVD analysis will be invalid. Based on the results of these tests, a VAR system is said to be stable if all the roots have modulus smaller than one.

\section{Co-integration Test}

Unrestricted Cointegration Rank Test (Trace)

Table 9 : Cointegration Test

\begin{tabular}{ccccc}
\hline \hline $\begin{array}{c}\text { Hypothesized } \\
\text { No. of CE(s) }\end{array}$ & Eigenvalue & $\begin{array}{c}\text { Trace } \\
\text { Statistic }\end{array}$ & $\begin{array}{c}0.05 \\
\text { Critical Value }\end{array}$ & Prob. $^{* *}$ \\
\hline \hline None $^{*}$ & 0.895083 & 135.3172 & 95.75366 & 0.0000 \\
At most 1 * & 0.824712 & 87.97083 & 69.81889 & 0.0009 \\
At most 2 * & 0.742718 & 51.40306 & 47.85613 & 0.0224 \\
At most 3 & 0.374646 & 22.89382 & 29.79707 & 0.2513 \\
At most 4 & 0.341960 & 13.03563 & 15.49471 & 0.1135 \\
At most 5 * & 0.183113 & 4.247333 & 3.841466 & 0.0393 \\
\hline \hline
\end{tabular}


Trace test indicates 3 cointegrating eqn(s) at the 0.05 level

* denotes rejection of the hypothesis at the 0.05 level

${ }^{* *}$ MacKinnon-Haug-Michelis (1999) p-values

Unrestricted Cointegration Rank Test (Maximum Eigenvalue)

\begin{tabular}{ccccc}
\hline \hline $\begin{array}{c}\text { Hypothesized } \\
\text { No. of CE }(\mathrm{s})\end{array}$ & Eigenvalue & $\begin{array}{c}\text { Max-Eigen } \\
\text { Statistic }\end{array}$ & $\begin{array}{c}0.05 \\
\text { Critical Value }\end{array}$ & Prob. $^{* *}$ \\
\hline \hline None $^{*}$ & 0.895083 & 47.34637 & 40.07757 & 0.0064 \\
At most 1 * & 0.824712 & 36.56777 & 33.87687 & 0.0233 \\
At most 2 * & 0.742718 & 28.50924 & 27.58434 & 0.0380 \\
At most 3 & 0.374646 & 9.858190 & 21.13162 & 0.7578 \\
At most 4 & 0.341960 & 8.788296 & 14.26460 & 0.3042 \\
At most 5 * & 0.183113 & 4.247333 & 3.841466 & 0.0393 \\
\hline \hline
\end{tabular}

Max-eigenvalue test indicates 3 cointegrating eqn(s) at the 0.05 level

* denotes rejection of the hypothesis at the 0.05 level

**MacKinnon-Haug-Michelis (1999) p-values

Unrestricted Cointegrating Coefficients (normalized by $\left.b^{\prime *} S 11^{*} b=I\right)$ :

Source : Eviews (2020, reprocessed)

Based on the above table, it can be seen that the value of trace statistic and maximum eigenvalue at $\mathrm{r}=0$ is greater than the critical value with a significance level of $1 \%$ and $5 \%$. This means that the null hypothesis which states that there is no co-integration is rejected and the alternative hypothesis which states that there is co-integration is accepted. Based on the econometric analysis above, it can be seen that among the four variables in this study, there is one co-integration at a significance level of $1 \%$ and $5 \%$. Thus, the results of the co-integration test indicate that between the movements of CONS, EKS, GDP and IMP have a stability or balance relationship and the similarity of movements in the long run. In other words, in each short-term period, all variables tend to adjust to each other, to achieve their long-term equilibrium.

\section{Error Vector Estimation}

Table 10: Estimated Vector Error

\begin{tabular}{llll}
\hline No & \multicolumn{1}{c}{ Variabel } & Koefisien & t statistik \\
\hline 1. & BI Rate & 2.81019 & -14.4028 \\
\hline 2. & Inflasi & 2.80520 & -0.75590 \\
\hline 3. & Jumlah Uang Beredar & 0.99388 & -27.0056 \\
\hline 4. & Nilai Tukar Rupiah & 0.59171 & 5.72035 \\
\hline 5. & Perkembangan Ekonomi & 2.62261 & -2.45727 \\
\hline
\end{tabular}

Source: Eviews (2020, reprocessed)

From table 10, it can be seen that the long- term effect of each variable can be explained as follows:

1. BI has positive effect but not significant at 2,81019 . Where it can be interpreted that when the BI Rate in the previous quarter increased by one percent, the change in sukuk supply in this quarter is 2,81019 percent . 
2. Inflation has positive effect but not significant at 2,80520. Where it can be interpreted that when inflation in the previous quarter increased by one percent then the change in sukuk supply in this quarter is 2,80520 percent .

3. Total Money Supply has no significant positive effect at 0,99388 . Where it can be interpreted that when the Total Money Supply in the previous quarter increased by one percent, the change in supply of sukuk in this quarter is 0,99388 percent .

4. Foreign Exchange Rate against Rupiah has positive significant effect at 0,59171. Where is the things that can be interpreted that when Rupiah Exchange Rate at previous quarter was rising by one percent then change deals sukuk in this quarter is to 0,59171 percent.

5. Indonesia's Economy Developments affect positively but not significant at 2,62261. Where it can be interpreted that when the Indonesian Economic Development in the previous quarter increased by one percent then changes in sukuk supply in this quarter is 2.62261 percent

\section{CONCLUSIONS AND RECOMMENDATIONS}

\section{Conclusion}

1. The results of the long-term VECM estimation test show that all macroeconomic variables have no significant effect on corporate sukuk supply in Indonesia. Except the exchange rate of the rupiah which has a significant effect on the supply of corporate sukuk in Indonesia.

2. The short-term VECM estimation test results show that only total money supply has effect on the supply of corporate sukuk in Indonesia. All macroeconomic variables have no significant effect on corporate sukuk offerings in Indonesia. Except the exchange rate of the rupiah which has a significant effect on the supply of corporate sukuk in Indonesia.

\section{Suggestion}

1. For Further Researcher

In the next research, it is expected to use unlimited financial ratios and not only use objects of service companies in the retail trade sector, and to use broader research objects.

2. For the Company

The results of this study are used as a reference in predicting bankruptcy, especially retail service sector companies with $75 \%$ accuracy, but also use other references in determining the Early Warning System before bankruptcy.

3. For Investors

The results of this study can be used as a reference in deciding to allocate funds.

\section{REFERENCE}

Amiran. (2012). Pengaruh Pertumbuhan Ekonomi, Inflasi dan Pertumbuhan Penduduk Terhadap Distribusi Pendapatan di Indonesia Periode 1986- 2010. Skripsi pada Jurusan Pendidikan Ekonomi Universitas Pendidikan Indonesia. Bandung.

Diakses tanggal 19 Februari 2020 pukul 11.13 WIB pada laman resmi www.bi.go.id/id/moneter/bi-rate/data/Default.aspx.

Diakses tanggal 19 Februari 2020 pukul 11.14 WIB pada laman resmi www.bi.go.id/id/moneter/inflasi/data/Default.aspx. 
Diakses tanggal 19 Februari 2020 pukul 11.15 WIB pada laman resmi www.bi.go.id/id/moneter/informasi-kurs/transaksi-bi/Default.aspx.

Gujarati, D. 2003. Ekonometrika Dasar. Zain, Sumarno [penerjemah]. Jakarta: Erlangga.

Khairunnisa. (2009). Analisis VECM (Vector Error Correction Model) dalam Mekanisme Pemodelan dan Peramalan Kebijakan Harga Pangan. Skripsi pada Departemen Statistika Institut Pertanian Bogor. Bogor.

Mankiw, G.N. (2006). Makroekonomi (Edisi Keenam). Jakarta: Erlangga.

Putong. (2007). Economics Pengantar Mikro dan Makro edisi 5. Jakarta: Wacana Media.

Rosadi, D., 2011. Ekonometrika dan Analisis Runtun Waktu Terapan dengan Eviews. Yogyakarta: C.V ANDI OFFSET.

Samuelson, A.P. dan Nordhaus, D.W.(2004). Ilmu Makro Ekonomi (Edisi Tujuh Belas). Jakarta: PT. Media Global Edukasi.

Sasmita, Yogi Chandra. Penerapan Model Vector Error Correction (VEC) pada Inflasi di Indonesia yang Dipengaruhi oleh Harga Minyak Mentah Dunia. Jurnal. Jurusan Matematika Universitas Brawijaya, Malang, Indonesia.

Sinay, Lexy Janzen. (2014). Pendekatan Vector Error Correction Model untuk Analisis Hubungan Inflasi, BI Rate dan Kurs Dolar Amerika Serikat. Jurnal Barekeng. Jurusan Matematika Universitas Pattimura Maluku, Indonesia, 8(2), hlm. 9-18.

Sitopu, Wajibman. (2013). Pemahaman Mendalam Bagaimana Konsep dan Tujuan Penggunaan Analisis Time Series Vector AutoRegressive (VAR) dan Vector Error Correction Model (VECM). [Online]. Tersedia: http://wajibstat.blogspot.co.id/2013/05/pemahaman-mendalam-

bagaimana-konsep-dan.html?m=1. [4 Januari 2017].

Sitorus, Bob Marshall. (2013). Analisis Peramalan Penjualan Sepeda Motor Honda Tipe Bebek, Matik, dan Sport di PT. Catur Putra Jaya Menggunakan Metode Kointegrasi. Skripsi pada Departemen Manajemen Institut Pertanian Bogor. Bogor.

Sukirno, Sadono.(2008). Makroekonomi Teori Pengantar (Edisi Ketiga). Jakarta : PT. Raja Grafindo Persada.

Sulastri, M. (2014). Analisis Faktor-Faktor yang Mempengaruhi Nilai Tukar Rupiah atas Dollar Amerika Serikat Periode 2004Q.1-2013Q.3. Skripsi pada Jurusan Pendidikan Ekonomi Universitas Pendidikan Indonesia. 